\title{
Morphometric and Morphological Analysis of Neuromuscular Junction Alterations in the Denervated Rat Diaphragm
}

\author{
Evaluación de las Alteraciones Morfológicas y Morfométricas \\ de las Uniones Neuromusculares del Diafragma Denervado en Ratas
}

${ }^{*}$ M. M. Torrejais; ${ }^{* *}$ J. C. Soares; ${ }^{* *}$ S. M. M. Matheus; ${ }^{* * *}$ J. M. Mello; ${ }^{* *}$ L. A. D. Francia-Farje \& ${ }^{* * * * *}$ E. J. D. Vicente

TORREJAIS, M. M.; SOARES, J. C.; MATHEUS, S. M. M.; MELLO, J. M.; FRANCIA-FARJE, L. A. D. \& VICENTE, E. J. D. Morphometric and morphological analysis of neuromuscular junction alterations in the denervated rat diaphragm. Int. J. Morphol., 27(4):1235-1242, 2009.

SUMMARY: The morphological and structural alterations that occur in the neuromuscular junctions of the denervated rat diaphragm were studied. Fifteen adult male albino rats (Rattus norvegicus) aged about 60 days and with a mean weight of $200 \mathrm{~g}$ were used. Chronically denervated diaphragms were obtained and the animals were sacrificed after 4, 8 and 12 weeks of denervation. The left antimere of the diaphragm was denervated by section of the phrenic nerve and the right antimere was used as control. Each antimere was divided into three fragments: one was used for histochemical (nonspecific esterase) and morphometric study of neuromuscular junctions, and the other two were used for transmission and scanning electron microscopy (SEM) analysis. Histochemical analysis of the diaphragm neuromuscular junctions after denervation showed only small changes in junction morphology. However, these junctions became smaller and elongated and presented less visible contours with increasing time of denervation. Ultrastructural analysis of neuromuscular junctions after 12 weeks showed more or less organized junctional folds on the muscle fiber surface. The junctional cytoplasm exhibited important alterations such as mitochondrial degeneration and the presence of numerous filaments. SEM revealed the presence of deep primary synaptic grooves with peripheral excavations which housed the nerve terminal boutons and exhibited internally the secondary synaptic clefts present among the junctional folds of the sarcolemma. This study showed that some of the morphological changes demonstrated in other denervated striated skeletal muscles are not repeated at the same intensity or in the same temporal pattern in the rat diaphragm.

KEY WORDS: Diaphragm; Neuromuscular junction; Denervation; Rat.

\section{INTRODUCTION}

Each striated skeletal muscle fiber individually receives nerve impulses from a motor neuron in a highly specialized contact region, called neuromuscular junction (NMJ). At this site, the action potential of a nerve induces the release of a chemical transmitter, acetylcholine, which acts on the muscle fiber membrane, initiating an action potential (Walton, 1988).

The NMJs of all vertebrates basically share the same structure: 1) an axon terminal containing the neurotransmitter acetylcholine; 2) Schwann cells and their cytoplasmic prolongations that cover the axon terminal, except for the presynaptic membrane, maintaining it attached to the primary synaptic groove; 3) a cleft measuring about $500 \AA$ in width which contains acetylcholine esterase and is lined by a basal lamina - the primary synaptic groove; 4) a postsynaptic membrane corresponding to a specialized region of the sarcoplasmic membrane which contains acetylcholine receptors, and 5) the junctional sarcoplasm which structurally and metabolically supports the postsynaptic region. However, the shape and size of the axon terminal, as well as the complexity of the pre- and postsynaptic membranes of the neuromuscular synapse, vary among the different types of muscle fibers (Ogata, 1988).

Matsuda et al. (1988) studied NMJs in the hamster long peroneal muscle after different periods of denervation (2, 4, 8 and 16 weeks) and reinnervation (4, 10 and 20 weeks)

\footnotetext{
* Medical and Pharmaceutic Sciences Center - UNIOESTE - Cascavel - Paraná - Brazil

** Department of Anatomy - IB - UNESP - Botucatu - São Paulo - Brazil

*** Department of Morphophysiological Sciences - UEM - Maringá - Paraná - Brazil

*****Department of Physiotherapy - UFJF - Juiz de Fora - Minas Gerais - Brazil
} 
TORREJAIS, M. M.; SOARES, J. C.; MATHEUS, S. M. M.; MELLO, J. M.; FRANCIA-FARJE, L. A. D. \& VICENTE, E. J. D. Morphometric and morphological analysis of neuromuscular junction alterations in the denervated rat diaphragm. Int. J. Morphol., 27(4):1235-1242, 2009.

by scanning electron microscopy (SEM). One week after nerve section, the synaptic grooves seemed to be more shallow and were accompanied by lowered sarcoplasmic ridges. After 4 weeks, the subneural apparatus was elevated above the sarcolemma as a flat plate, which persisted as a fusiform bulge for more than 8 weeks. There was a rapid and progressive decrease in the number of junctional folds. No trace of the subneural apparatus was observed after 16 weeks. Four weeks after nerve suture, the synaptic grooves were flattened but did not present the plate-like elevation. At 10 weeks, deep synaptic grooves started to be restored and an increase in the number of junctional folds was observed. Structural organization and recovery of the subneural apparatus were observed by week 20 .

Since the diaphragm is a striated skeletal muscle with special functional characteristics considering its uninterrupted activity throughout the life of a healthy individual, this muscle is an attractive model for the study of events associated with the process of denervation. Another relevant aspect is that the normal hemidiaphragm, in addition to satisfactorily maintaining the respiratory conditions of the animal, serves as a control for morphological or functional evaluation.

The objective of the present study was to study the morphological and morphometric features (light microscopy) and ultrastructural characteristics (TEM and SEM) of NMJs in diaphragms of albino rats after different periods of denervation.

\section{MATERIAL AND METHOD}

All experimental procedures were conducted in accordance with the ethical guidelines adopted by the Brazilian College on Animal Experimentation (COBEA) and were approved by the Ethics Committee on Animal Experimentation (CEEA).

Fifteen adult male albino rats (Rattus norvegicus) aged about 60 days and with a mean weight of $200 \mathrm{~g}$, obtained from the Central Animal House of Botucatu Campus, UNESP, São Paulo, Brazil, were used. The animals were anesthetized by intraperitoneal injection of $3 \%$ sodium pentobarbital $(1.0 \mathrm{ml} / \mathrm{kg})$. Preparations of chronically denervated diaphragms were obtained according to the technique described by Vital-Brazil (1965) for rats.

Five animals each were sacrificed after 4, 8 and 12 weeks of denervation. The left antimere of the diaphragm was used for the experiment and the right antimere served as control. Each hemidiaphragm was divided into three fragments: one was used for histochemical and morphometric study of NMJs, and the other two were used for TEM and SEM analysis.

Anatomical Observations. For anatomical study of the denervated diaphragms, specimens were removed en bloc, i.e., the muscle attached to the most caudal wall of the rib cage which comprises a segment of the spine, part of the sternum and more caudal ribs.

Histochemical Analysis of Neuromuscular Junctions. The diaphragm muscle was removed, extended and fixed on a plastic frame with staples to prevent its retraction during processing. Next, the muscle was immersed in $2.5 \%$ glutaraldehyde for 1 hour at room temperature and cut longitudinally into three or four slices with a razor blade. The sections were submitted to nonspecific esterase reaction according to the technique of Lehrer \& Ornstein (1959). Microscopic analysis and photodocumentation were performed using a Zeiss Axiophot II photomicroscope.

Morphometric Analysis of Neuromuscular Junctions. We used three slides per animal of normal hemidiaphragms and diaphragms denervated for 4, 8 and 12 weeks and prepared for histochemical analysis. The area and major and minor diameter of $50 \mathrm{NMJ}$ s were determined for each animal using a computerized image analysis system (KS-300, Zeiss).

Statistical Analysis. The morphometric parameters (area, major and minor diameter) obtained for the two treatments (control and denervated) after the three periods of time (4, 8 and 12 weeks) were analyzed by analysis of variance in a 2 $\mathrm{x} 3$ factorial scheme (treatment $\mathrm{x}$ period) using a completely randomized design. This analysis was complemented by multiple comparisons of treatment means for the same period and between periods for the same treatment (Norman \& Streiner, 1994).

Transmission Electron Microscopy of Neuromuscular Junctions. For this analysis, the muscle was removed, cut into fragments of about $1 \mathrm{~cm}$ and fixed in $2.5 \%$ glutaraldehyde. The fragments were submitted to nonspecific esterase reaction to identify the subsynaptic apparatus of NMJs. The muscle fragments thus prepared were also used for SEM study. Next, the muscles were cut into small longitudinal fragments measuring approximately $1 \mathrm{~mm}$ in width. The fragments were immersed in $2.5 \%$ glutaraldehyde and submitted to routine TEM processing.

Scanning Electron Microscopy of Neuromuscular Junctions. For SEM, the muscle was cut into fragments at intervals of $0.5 \mathrm{~cm}$ and the fragments were immersed in $2.5 \%$ 
glutaraldehyde for 24 hours. Next, the fragments were washed several times in 0.2 M phosphate buffer, $\mathrm{pH} 7.4$, and submitted to connective tissue digestion according to the technique of Desaki \& Uehara (1981) as follows: the material was washed in $0.2 \mathrm{M}$ phosphate buffer, pH 7.4 and the muscle fragments were incubated in $8 \mathrm{~N} \mathrm{HCl}$ for 40 min in a water bath at $60^{\circ} \mathrm{C}$ under constant shaking. Once the ideal time of acid digestion was determined for each muscle, the fragments were washed again in $0.2 \mathrm{M}$ phosphate buffer, $\mathrm{pH} 7.4$, and incubated in type II collagenase solution $(1 \mathrm{mg} / \mathrm{ml}$ in 0.1 M phosphate buffer, $\mathrm{pH} 6.8$ ) for 5 to 6 hours at $37^{\circ} \mathrm{C}$ (Ushiki \& Ide, 1988). The material was again washed several times in $0.2 \mathrm{M}$ phosphate buffer, $\mathrm{pH} 7.4$, followed by immersion in $2.5 \%$ glutaraldehyde and routine processing for SEM examination.

\section{RESULTS}

Anatomical Observations. Observation of the denervated muscles after 4 weeks showed that the left hemidiaphragm submitted to section of the corresponding phrenic nerve was more translucent, with muscle fibers being rare but still visible. In animals sacrificed after 8 and 12 weeks, the same diaphragmatic portion was completely translucent and muscle fibers were missing close to the tendinous center. However, muscle fibers were observed close to the ribs, a finding characterizing peripheral innervation of the diaphragm originating from the intercostal nerves.

Analysis of these specimens by transillumination permitted perfect control of the efficacy of the denervation procedures performed at the beginning of the study.

Histochemical Analysis of Neuromuscular Junctions. Intact preparations reacted for acetylcholinesterase were used for the morphological analysis of diaphragm NMJs of control and denervated rats after 4, 8 and 12 weeks. In the control group, the NMJs presented the classical plate-like morphology. Reaction with nonspecific esterase permitted
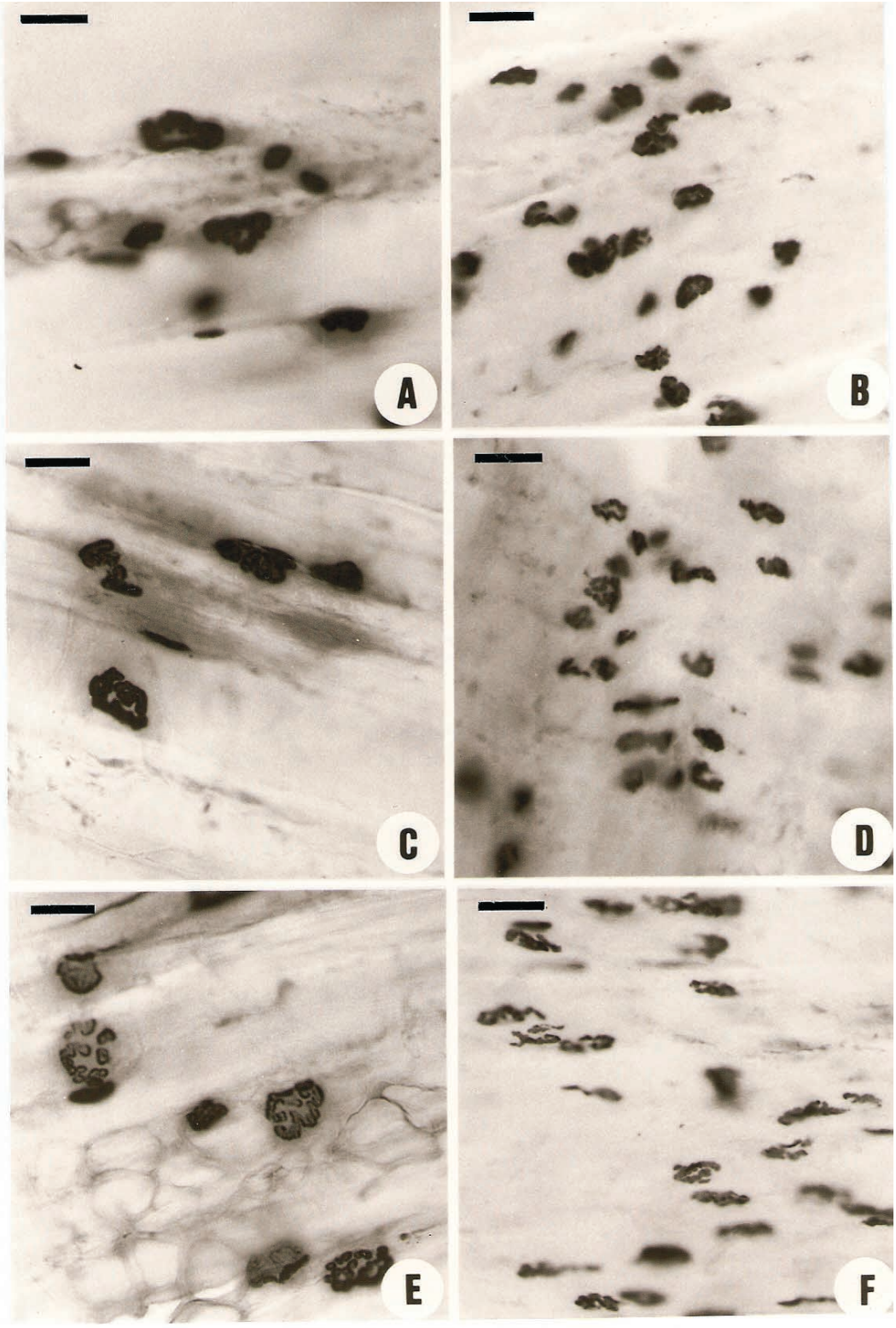

Fig 1. Photomicrographs of intact rat diaphragm preparations after nonspecific esterase reaction. A, C and E: Observe the neuromuscular junction polymorphism in controls after 4, 8 and 12 weeks, respectively. Bar $=25 \mu \mathrm{m}$. B, D and F: The neuromuscular junctions are smaller and elongated and present less visible contours in the denervated groups after 4, 8 and 12 weeks, respectively. Bar $=25 \mu \mathrm{m}$.

the observation of oval, round or elliptical NMJs. Variations in the shape of these junctions (irregular or compact) were occasionally observed and characterize the polymorphism of these structures seen in different muscles (Figs. 1A, 1C and 1E).

After denervation, only small alterations in NMJ morphology were observed over time, with these junctions becoming more elongated and smaller and presenting less visible contours (Fig. 1B, 1D and 1F). 
Morphometric Analysis of Neuromuscular Junctions. Some alterations in NMJ morphometry were observed and are shown in Tables I, II and III. The NMJ area was larger in diaphragms of control animals compared to the denervated groups, with this difference being statistically significant. In the control group, the NMJ area increased progressively in size over time but the difference was not significant. In contrast, a significant increase in NMJ area was observed in denervated animals between 4 and 12 weeks. These variations are shown in Table I.
As expected, the major diameter of NMJs showed a trend similar to that observed for the junction area (Table II). These morphometric data confirm the morphological observations showing apparent elongation of the NMJs in denervated diaphragms over time.

With respect to the minor diameter of NMJs, results similar to those obtained for junction area and major diameter were observed when comparing the control and denervated groups. However, a significant increase in minor diameter over time was observed for denervated animals (Table III).

Table I. Mean, standard deviation and the result of the statistical test for the comparison of neuromuscular junction area according to treatment and time of sacrifice.

\begin{tabular}{lccc}
\hline Treatment & \multicolumn{3}{c}{ Time of sacrifice } \\
\hline \multirow{4}{*}{ Control } & 4 Weeks & 8 Weeks & 12 Weeks \\
Denervated & $564.11 \pm 50.42 \mathrm{~b} \mathrm{~A}$ & $611.99 \pm 146.51 \mathrm{~b} \mathrm{~A}$ & $623.53 \pm 75.80 \mathrm{~b} \mathrm{~A}$ \\
\hline
\end{tabular}

Table II. Mean, standard deviation and the result of the statistical test for the comparison of the major diameter of neuromuscular junctions according to treatment and time of sacrifice.

\begin{tabular}{lccc}
\hline Treatment & \multicolumn{3}{c}{ Time of sacrifice } \\
\hline & 4 Weeks & 8 Weeks & 12 Weeks \\
Control & $34.84 \pm 1.44 \mathrm{~b} \mathrm{~A}$ & $35.93 \pm 4.12 \mathrm{~b} \mathrm{~A}$ & $37.00 \pm 2.33 \mathrm{~b} \mathrm{~A}$ \\
Denervated & $29.43 \pm 4.30 \mathrm{a} \mathrm{A}$ & $30.27 \pm 1.77 \mathrm{a} \mathrm{AB}$ & $33.34 \pm 1.00 \mathrm{a} \mathrm{B}$ \\
\hline
\end{tabular}

Table III. Mean, standard deviation and the result of the statistical test for the comparison of the minor diameter of neuromuscular junctions according to treatment and time of sacrifice.

\begin{tabular}{lccc}
\hline Treatment & \multicolumn{3}{c}{ Time of sacrifice } \\
\hline Control & 4 Weeks & 8 Weeks & 12 Weeks \\
Denervated & $22.26 \pm 1.03 \mathrm{~b} \mathrm{~A}$ & $22.79 \pm 2.85 \mathrm{~b} \mathrm{~A}$ & $23.13 \pm 1.33 \mathrm{~b} \mathrm{~A}$ \\
\hline
\end{tabular}

Ultrastructural Analysis of Neuromuscular Junctions. Ultrastructural analysis of NMJs was highly difficult in the present study. Several samples were processed for the observation of normal junctions and those exhibiting eventual structural alterations. After labeling with nonspecific esterase, the muscle could be reduced more effectively for the demonstration of synapses. The NMJs of control hemidiaphragms presented normal features such as those observed in other striated skeletal muscles (Fig. 2). Despite relative success, it could be demonstrated that the muscle fiber surface still exhibited more or less organized junctional folds in animals submitted to denervation for 12 weeks. However, the junctional folds were irregularly distributed and some were wider. Facing the top of the junctional folds of the sarcolemma, dense collagen bundles and, in some situations, the presence of Schwann cells were observed. The juxtajunctional sarcoplasm presented an exuberant number of filaments and mitochondria in different stages of degeneration (Fig. 3A and 3B).

Greater difficulties were encountered during analysis of the muscle fiber surface in order to demonstrate the characteristics of abandoned synaptic grooves after nerve section. The proliferation of connective tissue observed in denervated muscles greatly impaired the dissolution of this tissue in $\mathrm{HCl}$. Thus, most specimens presented large amounts of interposed connective tissue which impaired ultrastructural analysis. However, analysis of diaphragms after 2 weeks of denervation showed that the primary synaptic groove of NMJs maintained the normal 


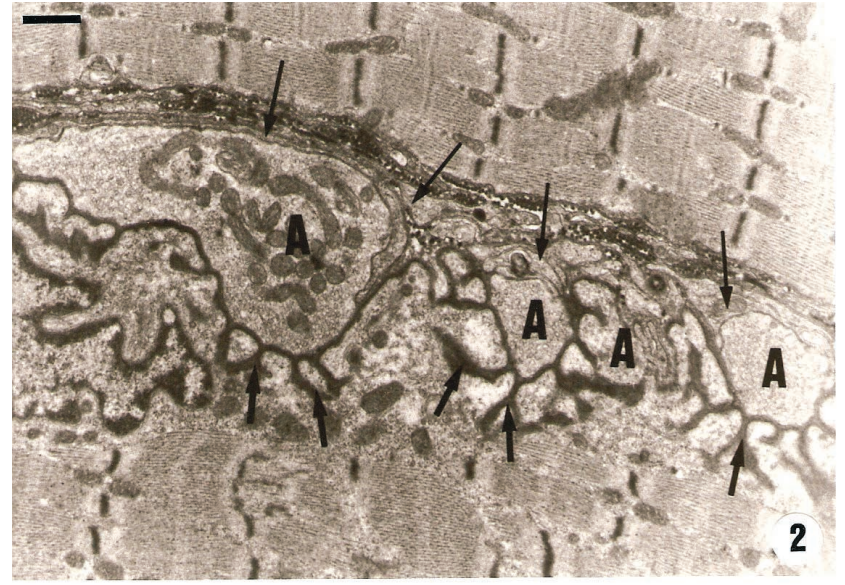

Fig. 2. Transmission electron photomicrographs of longitudinal sections of control rat diaphragm. Simple plate-like neuromuscular junctions can be seen. Note the axon terminals (A) containing mitochondria and synaptic vesicles which are close to one another and are inserted in the synaptic grooves. Clearly visible junctional folds demonstrated by nonspecific esterase reaction (short arrows) and Schwann cell prolongations covering the axon terminals can be seen (thin arrows). Bar $=0.75 \mu \mathrm{m}$.

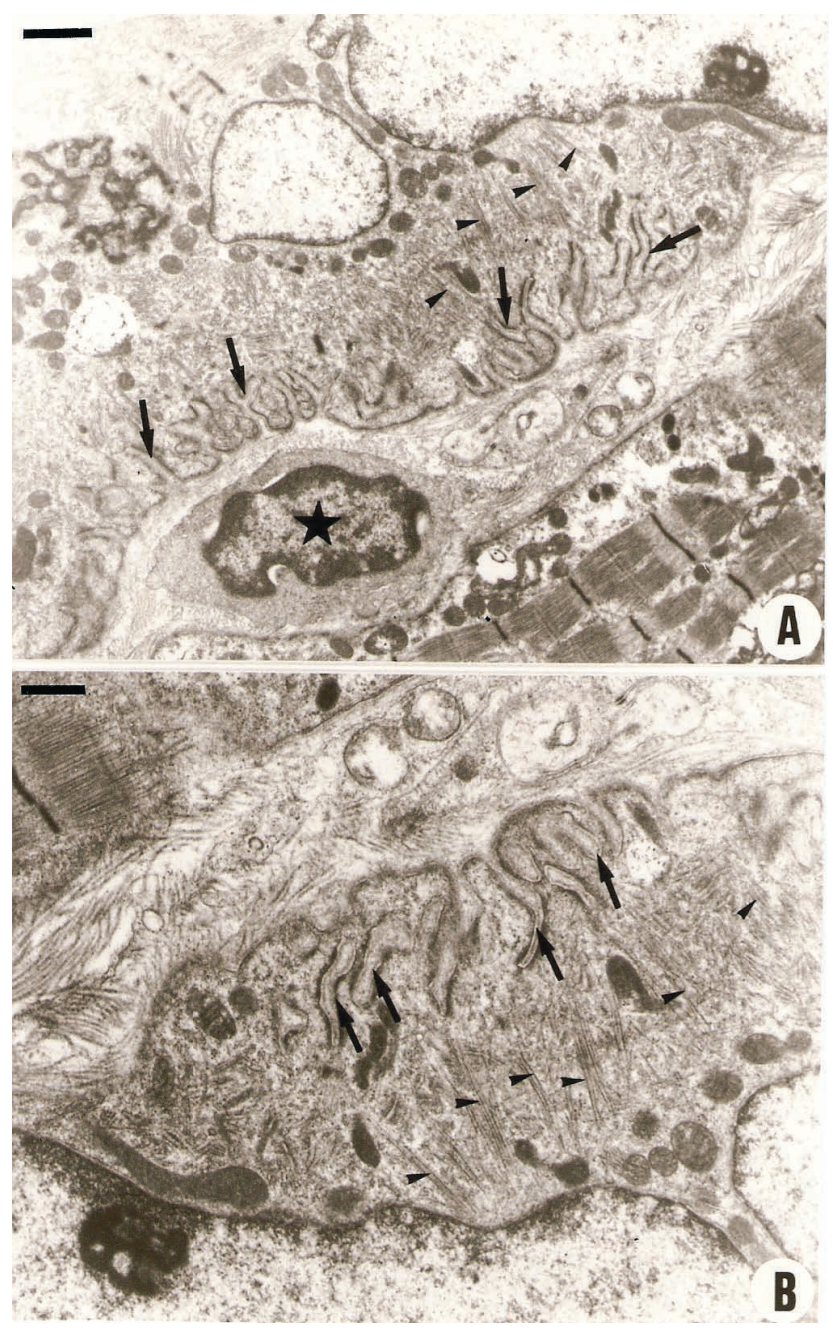

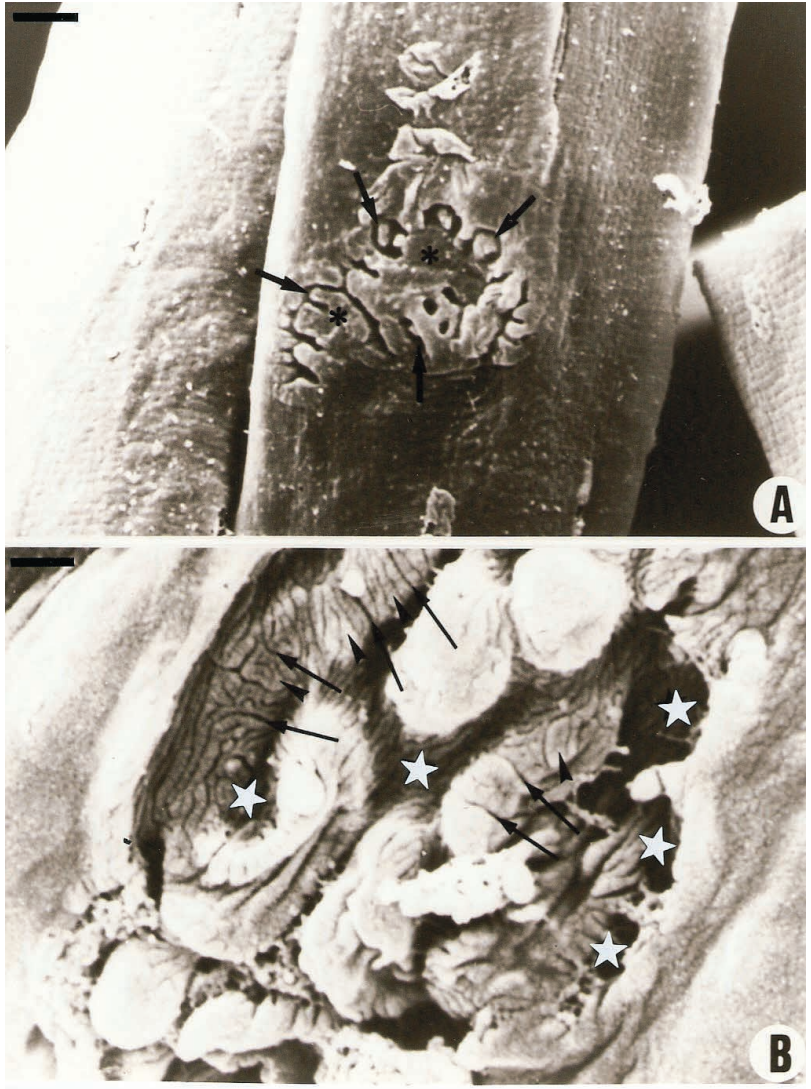

Fig. 4. Scanning electron photomicrographs of neuromuscular junctions of control rat diaphragm obtained after digestion of connective tissue with $\mathrm{HCl}$. A: Primary synaptic grooves (arrows) and sarcolemmal projections ( $)$. Bar $=33.33 \mu \mathrm{m}$. B: Primary synaptic grooves $(\mathrm{H})$, secondary synaptic clefts (thin arrows), and junctional folds of the sarcolemma (arrowheads). Bar $=5.92$ $\mu \mathrm{m}$.

characteristics observed in other muscles. The grooves were deep as observed for controls (Fig. 4A and 4B), presented the peripheral excavations that housed the nerve terminal boutons and exhibited internally the secondary synaptic clefts among junctional folds of the sarcolemma (Fig. 5A and $5 \mathrm{~B})$.

Fig. 3. Transmission electron photomicrographs of longitudinal sections of denervated rat diaphragm fibers after 12 weeks. A and B: Nonspecific esterase reaction shows that the muscle fiber surface still exhibits more or less organized, irregularly distributed junctional folds (long arrows), some of them very wide. The presynaptic region is occupied by dense collagen bundles, a Schwann cell $(\mathrm{H})$ and various degenerated mitochondria. An exuberant quantity of filaments is observed in the juxtajunctional sarcoplasm (arrowheads). Bar $=1.03 \mu \mathrm{m}$ and $0.59 \mu \mathrm{m}$, respectively. 


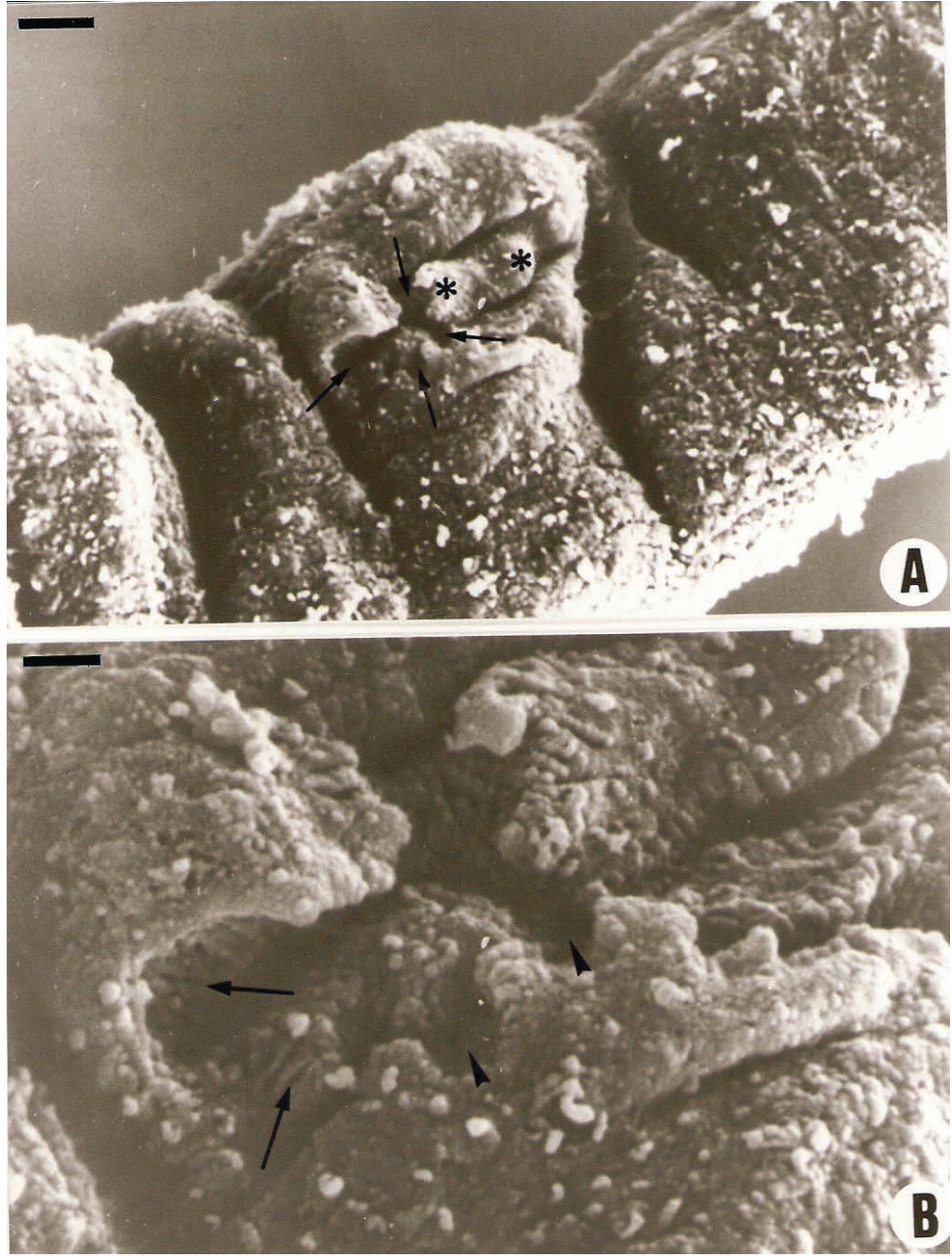

Fig. 5. Scanning electron photomicrographs of neuromuscular junctions of denervated rat diaphragm at 2 weeks obtained after digestion of connective tissue with $\mathrm{HCl}$. A: Note the deep primary synaptic grooves (arrows) and sarcolemmal projections $(\backslash)$. Bar $=18.18 \mu \mathrm{m}$. B: Deep primary synaptic grooves with peripheral excavations housing the nerve terminal boutons (arrowheads); secondary synaptic clefts (arrows). Bar $=4.76 \mu \mathrm{m}$.

\section{DISCUSSION}

Denervation of the rat diaphragm was successful as demonstrated by the gross inspection of specimens removed en bloc and examined by transillumination. The procedure proposed by $\mathrm{Vi}$ tal-Brasil was simple, rapid and successful as indicated by the low morbidity considering the extent and location of the surgical injuries.

Analysis of NMJ morphology over the experimental period revealed changes in the classical, usually elliptical or round, shape of these structures, with the junctions becoming less regular and scattered and presenting altered affinity for acetylcholinesterase as demonstrated by irregular and pale staining. In fact, these images represent the primitive arrangement of the basal lamina where the enzyme is found above the original synaptic groove. After injury, the nerve endings disappear within a latency period of 12 hours during which the nerve ending appears normal. The duration of this period depends on the proximity between the nerve injury and the muscle studied. Over the next 8 to 10 hours, synaptic vesicles agglutinate, mitochondria become dilated and nerve endings are fragmented and then phagocytosed by synaptic Schwann cells (Miledi \& Slater, 1970). After this phase, the Schwann cell occupies the synaptic groove for some weeks until neuronal regeneration or, if this is not the case, the groove is disoccupied.

Certainly, the entire degenerative process undergone by muscle fibers after denervation reflects on the morphology of the "silhouette" of NMJs submitted to reaction with acetylcholinesterase. The "elongation" of NMJs observed throughout denervation might be associated with the progressive loss of contractile elements and consequent tapering of muscle fibers. The increase in the size of NMJs observed in the denervated muscle is in fact related to the growth of the animal as a whole and not of the junctions themselves. This aspect can be easily inferred when comparing the progressive growth of NMJs in the normal antimeres of the diaphragm. Although it seems paradoxical, the demonstration of a significant increase of minor diameter in denervated animals might be related to the measurement procedure. During measurement, the NMJs are selected in such a way that only those arranged in parallel to the observation plane are evaluated. This procedure is justified by the fact that NMJs in a position oblique or tangential to the muscle fiber in relation to the observation plane might distort the results. Since the increase in minor diameter was more marked during the first phase of denervation ( 4 to 8 weeks), a reasonable explanation would be that the muscle fibers selected for measurement correspond to those which are still in the initial stage of degeneration, a stage characterized by nerve fiber edema, among other events, as observed for type I fibers during spinal muscular atrophy (Fenichel \& Engel, 1963).

Ultrastructural analysis contributes to the understanding of the mechanisms underlying 
cellular disease and provides etiological evidence of neuromuscular disorders. One of the first alterations that are observed in various muscle diseases is the occurrence of papillary projections, an increase in the number of pinocytic vesicles, the presence of longitudinal folds during the process of muscle fiber splitting, rupture of the sarcoplasmic membrane with local losses of exocytosis points or in small necrotic areas or even large losses in extensive necrotic areas, disappearance of the sarcoplasmic membrane, and changes in the basal lamina (Engel \& Banker, 1994).

The undulated projections of the sarcolemma observed in muscle fiber regions after 4 weeks of denervation may reflect the loss of cytoplasmic substance, which results in structural adaptation of the membrane when part of the cellular material is expelled by exocytosis. Another explanation is the expulsion of sarcomeres by contraction of normal sarcomeres in neighboring regions or due to proteolytic digestion of myofilaments in focal sarcomere lesions (Banker \& Engel). As demonstrated in this study, focal sarcomere lesions associated with structural alterations in myofibrils and disorganization of muscle fiber banding might explain the occurrence of superficial sarcolemmal projections. These projections are filled with pinocytic vesicles and are always covered with basal lamina. However, Banker \& Engel did not specifically mention this aspect as part of the process of denervation as observed in the present study.

With respect to $\mathrm{NMJ}$, despite the numerous technical difficulties, late observations showed a reasonable sarcolemmal organization in the region of the primitive synapse. In addition to an altered fundamental nucleus, the subsarcolemmal region exhibited mitochondria in different stages of degeneration and abundance of filaments arranged among junctional folds and nerve fiber cytoplasm. Monitoring of eventual lesions was extremely difficult during the early phases of denervation because of difficulties in identifying these lesions. However, marked presynaptic modifications consisting of the complete absence of neural endings and the presence of Schwann cells and dense collagen bundles arranged at the ends of the junctional folds of the sarcolemma were observed. Similar findings have also been reported by Lüllmann-Rauch (1971) for rat diaphragms after 3 and 4 weeks of denervation.

According to Miledi \& Slater, experimental section of the motor nerve is followed by a latency period during which the nerve ending shows a normal aspect. The duration of this period depends on the distance of the injury. In the case of the rat diaphragm, the morphology of these endings continues to be normal for 8 to 12 hours after section of the phrenic nerve at the cervical level. Over the next 8 to 10 hours the mitochondria become dilated, synaptic vesicles agglutinate, and osmiophilic material accumulates in the nerve ending which is fragmented and phagocytosed by Schwann cells that may occupy the groove for weeks. In the absence of installation of the regeneration process, the Schwann cell retracts from the synaptic groove. The findings reported by Miledi \& Slater could not be evaluated during the initial phases of denervation because of the technical difficulties mentioned earlier. This fact may have impaired the observation made by Pulliam \& April (1979) that nerve endings disappear from the synaptic grooves as early as after 3 days of denervation in all types of muscle fibers. However, our late observations are compatible with the above descriptions. We found no studies in the literature commenting on the meaning of the filaments observed in junctional cytoplasm. According to Pulliam \& April, this region is characterized by disorganized and amorphous cytoplasm after denervation. One may suggest that the filaments observed, which presented a certain degree of organization, are associated with proliferation of thetubular system of the denervated muscle fiber.

The examination of the muscle fiber surface after digestion of connective tissue with $\mathrm{HCl}$ was also limited by the excess connective tissue present in the denervated diaphragm. Another limiting factor for execution of the technique was the difficulty in identifying the junctions on the surface of atrophic muscle fibers which, in most cases, were extremely retracted and presented surface undulations. Nevertheless, the relative integrity of the junctional folds described by TEM could be observed. The structure of the synaptic groove was found to be simpler when compared to controls, but did not resemble the observations of NMJs after 8 weeks of denervation made by Matsuda et al. for the hamster long peroneal muscle. These authors observed the formation of a fusiform bulge in the region of the $\mathrm{NMJ}$, the disappearance of the primary synaptic groove and flattening of the junctional folds. In addition, the secondary synaptic grooves became sparse and shallow. However, evaluation of a larger number of specimens is necessary to define in more detail the alterations that occur in NMJs after denervation of the diaphragm.

Analysis of the present results and their comparison with literature data permit the following conclusions: a) NMJs stained with nonspecific esterase present an unchanged morphology of the subsynaptic apparatus despite a progressive increase in its dimensions during the process of denervation; b) the morphological pattern of the postsynaptic membrane remains relatively intact in some muscle fibers even after 12 weeks of denervation. 
TORREJAIS, M. M.; SOARES, J. C.; MATHEUS, S. M. M.; MELLO, J. M.; FRANCIA-FARJE, L. A. D. \& VICENTE, E. J. D. Evaluación de las alteraciones morfológicas y morfométricas de las uniones neuromusculares del diafragma denervado en ratas. Int. J. Morphol., 27(4):1235-1242, 2009.

RESUMEN: En este trabajo se estudiaron las alteraciones morfológicas y estructurales de las uniones neuromusculares en el diafragma denervado de ratas. Se utilizaron 15 ratas albinas (Rattus norvegicus), machos, adultos, con peso promedio de $200 \mathrm{~g}$ y cerca de 60 días de edad. Los diafragmas crónicamente denervados fueron obtenidos y los animales se sacrificaron después de 4,8 y 12 semanas de denervación. El antímero izquierdo del diafragma fue denervado por sección del nervio frénico y el antímero derecho fue utilizado como control. Cada antímero fue dividido en 3 fragmentos: uno fue utilizado para el estudio histoquímico (esterasa inespecífica) y morfométrico. Los otros dos se destinaron al estudio de microscopía electrónica de transmisión (MET) y microscopia electrónica de barrido (MEB) de las uniones neuromusculares. El estudio histoquímico de las uniones neuromusculares posterior a la denervación, muestra que la morfología de esas uniones sufre pequeñas alteraciones. Con la evolución del tiempo de denervación esas uniones muestran tamaños menores, son alargadas y con contornos menos nítidos. La ultra-estructura de las uniones neuromusculares después de 12 semanas, demostró que la superficie de la fibra muscular exhibe pliegues de unión más o menos organizados. La región del citoplasma de unión exhibe alteraciones importantes, con degeneración mitocondrial y presencia de muchos filamentos. En MEB se observa que los botones sinápticos primarios son profundos, presentan escavaciones periféricas donde estaban alojados los botones de las terminaciones nerviosas y exhiben internamente, los espacios sinápticos secundarios presentes entre los pliegues de unión del sarcolema. Este estudio mostró que algunos patrones morfológicos demostrados en otros músculos estriados esqueléticos denervados no se repiten con la misma intensidad y curso temporal en el diafragma de ratas.

PALABRAS CLAVE: Diafragma; Unión neuromuscular; Desnervación; Rata.

\section{REFERENCES}

Banker, B. Q. \& Engel, A. G. Basic reactions of muscle. In: Engel, A. G. \& Frazini-Armstrong, C. Myology: basic and clinical. 2nd ed. New York, Edition International, 1994. pp.832-88.

Desaki, J. \& Uehara, Y. The overall morphology of neuromuscular junctions as revealed by scanning electron microscopy. $J$. Neurocytol., 10:101-10, 1981.

Engel, A. G. \& Banker, B. Q. Ultrastructural changes in diseased muscle. In: Engel, A. G. \& Frazini-Armstrong, C. Myology: basic and clinical. 2nd ed. New York, Edition International, 1994. pp.889-1017.

Fenichel, G. M. \& Engel, W. K. Histochemistry of muscle in infantile spinal muscular atrophy. Neurology, 3:1059, 1963.

Lehrer, G. M. \& Ornstein, L. A diazo coupling method for the electron microscopic localization of cholinesterase. Biophys. Biochem. Cytol., 6:399-419, 1959.

Lüllmann-Rauch, R. The regeneration of neuromuscular junctions during spontaneous re-innervation of the rat diaphragm. $Z$. Zellforsch., 121:593-603, 1971.

Matsuda, Y.; Oki, S.; Kitaoka, K.; Nagano, Y.; Nojima, M. \& Desaki, J. Scanning electron microscopic study of denervated and reinnervated neuromuscular junction. Muscle Nerve, 11:1266-71, 1988.

Miledi, R. \& Slater, C. R. On the degeneration of rat neuromuscular junctions after nerve section. J. Physiol., 207:507-28, 1970.
Norman, G. R. \& Streiner, D. L. Biostatisties: the bare essentials. St. Louis, Mosby, 1994. p.260.

Ogata, T. Structure of motor endplates in the different fiber types of vertebrate skeletal muscles. Arch. Histol. Cytol., 51:385424, 1988.

Pulliam, D. L. \& April, E. W. Degenerative changes at the neuromuscular junctions of red, white and intermediate muscle fibers. J. Neurol. Sci., 43:205-22, 1979.

Ushiki, T. \& Ide, C. A modified KOH - collagenase method applied to scanning electron microscopic observations of peripheral nerves. Arch. Histol. Cytol., 51:223-32, 1988.

Vital-Brazil, O. Ação neuromuscular da peçonha micrurus. Hospital, 68:909-50, 1965.

Walton, W. J. N. The anatomy and physiology of the motor unit. In: Disorders of voluntary muscle. 5nd ed. Edinburgh, Churchill Livingstone, 1988.

Correspondence to:

Prof. Dra. Marcia Miranda Torrejais

Medical and Pharmaceutic Sciences Center

University of the State of Paraná

UNIOESTE - 85814-110,

Cascavel

Paraná, BRAZIL

Email: torrejais@unioeste.br

Received: 13-07-2009

Accepted: 24-08-2009 